\title{
Using Commodities as Collateral for Finance (Commodity-Backed Finance)
}

Panos Varangis (Finance and Markets Global Practice) and Jean Saint-Geours (Trade and Competitiveness Global Practice $)^{1}$

\section{Introduction}

In most emerging markets, the lack of acceptable collateral is often cited as a key constraint on the provision of credit to agriculture. Three main types of collateral are typically used to finance agriculture: farmland, equipment, and agricultural commodities. In many economies, however, the ability to use farmland as collateral is hindered by the absence of land titles or by inefficient land markets. Likewise, mortgaging or leasing out equipment is not always possible due to the lack of mechanization in agriculture, the absence of a legal and regulatory framework conducive to leasing, or limited secondary markets for equipment in case of default. As a result, the third option-use of agricultural commodities as collateral-is increasingly being explored in various countries, particularly in Latin America, South Asia, and East Africa, where financial institutions have developed credit products that use commodities as collateral for lending. Such agricultural commodities have an established value and market where quick liquidation mechanisms can in theory provide sufficient funds to cover a loan extended against them in case of a default.

While commodity-backed finance refers to both pre-harvest finance (pledge of future production) and post-harvest finance (pledge of existing inventories), using commodities as collateral is more common for post-harvest finance for a few reasons. Post-harvest finance notably leverages tools (presented below) that are simpler to put in place-that is, securing existing commodities is a less challenging task than securing commodities that have yet to be produced.

As a result, commodity-backed finance using inventories as collateral should in theory enable borrowers to convert the riskier and more expensive credit they had been using to finance production to the more secure and better-priced credit after harvest. For traders and processors, the ability to access credit using commodities enables them to purchase the needed commodities during harvest, when their seasonal financing needs are significant and usually not covered by fixed assets. For producers and producer associations, the ability to access post-harvest credit enables them to sell their crop deliberately over time rather than all at once immediately after harvest, when prices are usually low. Thus, a financial instrument like commodity-backed finance can enable producer organizations and cooperatives to strengthen their negotiation power in the market by allowing them to defer sales until they are offered reasonable prices. It can also enable them to pay their members without having to wait for the actual sale of the products.

Overall, commodity-backed finance using agricultural inventories is an important component of a holistic approach to making agricultural credit and professional storage more accessible. In turn, more accessible credit and storage can contribute to food security by (1) increasing local food processing capacity; (2) reducing post-harvest losses; ${ }^{2}$ (3) improving the quality of the goods stored under better

\footnotetext{
${ }^{1}$ This note has benefited from peer review comments by Makiko Toyota, Heather Miller, and Simon Bell.
} 
conditions; and (4) potentially improving incomes for farmers (through a combination of lower postharvest losses and better prices from delayed marketing).

\section{Types of Commodity-Backed Finance Instruments Using Inventories as Collateral}

There are three main types of commodity-backed finance instruments using inventories as collateral: warehouse receipt systems, collateral management agreements, and stock monitoring agreements.

The warehouse receipt system (WRS) is a system that enables warehouse operators to issue receipts as evidence that specified commodities of stated quality and quantity have been deposited at a particular location by named depositor(s). The warehouse operator holds the stored commodity in safe custody, and the depositor can use the receipt as collateral to borrow from banks. In most emerging economies, ensuring the success of a WRS requires a dedicated legal and regulatory framework and a warehouse licensing and inspection authority. ${ }^{3}$

Farmers, traders, processors, and any other owners of commodities can deposit these commodities in such licensed and inspected third-party warehouses. Banks provide funding at some discount of the value of the warehouse receipt to account for the storage and financing costs, as well as factors such as price volatility history, the robustness of the system, and the trust they put in the warehouse operator. ${ }^{4}$ As a result, even though loans tend to be around 60-70 percent of the value of the crop, there can be significant variations, from as low as 50 percent to as high as 80 percent of the crop's value. When the depositor sells the receipt and therefore the underlying crop in storage, the bank must be paid by the buyer before it releases the receipt; once released, the receipt must be presented to the warehouse alongside payment of storage and handling costs and fees in order to have the inventories delivered to their new owner. Several countries have warehouse receipt systems in place, including Argentina, Brazil, Colombia, Cote d'Ivoire, Ghana, India, Indonesia, Kenya, Malawi, Mexico, South Africa, Tanzania, and others.

A collateral management agreement (CMA) is a three-party agreement between the commodity owner/borrower, the collateral manager, and a bank (although in some cases a fourth party, the buyer, is added). CMAs can be used in countries that do not have a formal WRS, but they can also coexist with a WRS. Under a CMA, the collateral management company issues a certificate of deposit that the borrower can use as collateral to obtain a loan. When the goods are sold, the bank gets paid first and then authorizes the collateral manager to release the inventories to the new owner. For greater security, the certificate of deposit can be registered at a collateral registry.

\footnotetext{
${ }^{2}$ There is, for instance, evidence of sharp decreases in post-harvest losses resulting from the warehouse receipt system (WRS) in Kenya (from 30 percent in government-run warehouses to 0.2 percent in WRS-linked warehouses), as documented by the ongoing World Bank Group project supporting the WRS in that country.

${ }^{3}$ It should be noted that other contract-based systems not using a dedicated legal and regulatory framework for warehouse receipt financing exist and can be successful, as evidenced by the case of South Africa.

${ }^{4}$ Even within a WRS, banks may prefer to deal with some but not all warehouse companies that issue warehouse receipts.
} 
The key issue in CMAs is the trust between the three parties, and particularly the trust in the specific collateral management company that ensures the integrity of the warehouse and the quantity (and sometimes the quality) of the goods stored and used as collateral. The collateral manager is a professional firm, usually comparatively large and well-capitalized, that has the skills to manage inventories and is trusted by the bank. Many collateral management firms offer performance guarantees, or have sufficient skills and capital, to ensure that banks are compensated even in cases of fraud. Some banks have their own fully-owned subsidiary collateral management company so they can exert better control over its operations (e.g., Banorte in Mexico).

A stock monitoring agreement (SMA) is an agreement by which an inspection company periodically monitors inventory levels (and sometimes the quality) of commodities stored or shipped to a location, with the aim of ensuring traceability. Traders and processors who hold inventories in their own warehouses often use SMAs to obtain seasonal credit for purchasing crop after harvest. Since the inventories that could be used to satisfy the loan are held on the owner's premises, banks use the services of a stock monitoring or inspection company to periodically (e.g., weekly or even daily) monitor the inventories.

This is a much less secure form of collateral compared to WRS and CMA for the banks. The degree of control over monitoring varies. In Ethiopia, for example, banks hold the key to the warehouse, and a bank employee is on standby to open the warehouse as needed, even though that warehouse belongs to the trader or cooperative. In Vietnam, banks post employees during working hours to supervise the warehouse of a processor or trader whose inventories they finance. In Mexico, stock monitoring is done by employees of a company hired by the bank to inspect warehouses randomly at least once a week. Banks tend to arrange SMAs with clients they have other financial dealings with and whom they trust. Clients who prefer SMAs are often processors who need the convenience of accessing inventories on their own premises to keep their production line moving.

It should be noted that CMAs and SMAs tend to rely on the usual contractual laws of the country and do not usually need the enactment of specific legislation. A WRS tends to rely on laws and regulations specifically related to the WRS, often within the broader context of a legal and regulatory framework for secured transactions. For example, countries with a WRS often have a dedicated warehouse receipts law and institutional arrangements for licensing and inspecting third-party warehouses that issue receipts. The additional cost and effort required to set up and operate a WRS can be justified by its increased reach and inclusiveness. CMAs and SMAs are often accessible only to more established players already having a track records with banks, and they tend to be concentrated in the country's main city or port. By contrast, a WRS can in theory offer access to commodity-backed financing to a wider range of market players, such as producers or smaller traders and processors; it does so by reducing the transaction cost related to due diligence for all the parties involved (the depositor, warehouse operator, and bank). Indeed, in Ethiopia and Tanzania, the volumes of crops transiting each year through a WRS add up to hundreds of thousands of tons; in South Africa, they add up to millions of tons. Moreover, about US\$45 million in loans have been facilitated through WRS, and 50,000 farmers have been reached through the 
incipient WRSs in Côte d'Ivoire, Kenya, and Malawi, whose development is being supported by ongoing World Bank Group projects. ${ }^{5}$

\section{Other Types of Financing Agreements Using Future Production as a Pledge}

In addition to financing using existing inventories as collateral, there are other types of commodity financing agreements that use future (pre-harvest) production as a pledge for financing.

Crop receipts are a form of pre-harvest finance instruments that allow farmers to access credit by pledging a future crop. A good example is the CPR (Cedula Producto Rural) system in Brazil. Although such a system offers benefits, it requires a large number of preconditions, since the pledge is for collateral that does not exist (the future crop) at the time the loan is granted. A lot of risks must be managed in order for banks to be comfortable lending against such future crop pledges; usually such systems require crop insurance, price hedging mechanisms, etc. to reduce such risks. Most beneficiaries of crop receipts in Brazil tend to be medium and larger commercial farmers. With all these preconditions, crop receipts are not very common outside Brazil, although recently there have been some efforts to pilot crop receipts in certain large grain markets in Eastern Europe and Central Asia.

Value chain finance in contract farming is another form of pre-harvest finance. It relies on new technologies in logistics, communication, product traceability, etc. that bring large buyers into contact with smallholder producers, and enable the provision of credit and other products and services to these smallholders. This form of finance is used within tight value chains in which a large buyer contracts (formally or informally) to purchase from farmers and also provides them with technical assistance, inputs, crop monitoring, price certainty, etc. In such circumstances, banks may be willing to finance farmers using such contracts as collateral. There are three main categories of value chain finance arrangements:

- Banks finance the off-taker (large buyer), which then finances the smallholders, usually by providing inputs for free and deducting the input costs when farmers deliver the crops. The buyer reimburses the loan to the bank in the end.

- Banks finance farmers directly through the off-taker. When farmers deliver crops to the buyer, the buyer is the one repaying the loan to the bank by deducting from the amount owed to the farmer the amount needed to repay the loan and sending it to the bank.

- The off-taker may take part of the risk (first-loss partial guarantee or risk share) to provide additional security to the bank regarding loan default.

There are also value chain finance arrangements in which an input supplier provides financing in the form of inputs to farmers through a local bank. Payment is deducted when the farmer delivers crops to the buyer. An example of such a scheme can be found in Ukraine, where the input supplier also provides a first-loss guarantee to the bank on the repayment. Perhaps the biggest risk in value chain finance is side selling, in which farmers deliver their crops to a buyer other than the one which

\footnotetext{
${ }^{5}$ These results are based on the impacts reported by these ongoing projects through their monitoring and evaluation systems as of May 31, 2017.
} 
provided pre-harvest finance and are therefore unable to repay the loan through the agreed upon deduction. Good monitoring of farmers by the buyer can reduce this risk, as can the structure of a well-organized and tight value chain (including, for example, central processing, premiums for quality, addressing perishability, links to high-value markets, etc.) and the physical characteristics of the commodity. Well-organized and tight value chains can be found in such commodities as poultry, dairy, cotton, sugar, aquaculture, fruits and vegetables, and high-value cash crops such as spices and specialty coffees and teas. Some relevant examples are dairy, poultry, and sugar finance in India, cotton finance in West Africa, and fruit and vegetable finance in South Africa, among many others.

In addition to the use of contracts (formal or informal) and purchase orders to finance future production, another form of value chain finance is receivable finance. In this approach, farmers obtain finance from banks with an invoice from the buyer issued after they deliver their crop that promises payment at a later date (e.g., in 30,60, or 90 days). The main risk for such receivable finance is that the buyer (usually a large local or international company) will not pay; from the bank's perspective, this is more or less equivalent to the buyer's credit risk, which should be much lower than the farmer's. In effect, receivable finance converts the credit risk of the farmer into the credit risk of the buyer. Several countries (Chile, China, and Mexico, among others) have dedicated receivable finance platforms that enable various financial institutions to finance invoices and receivables.

\section{Requirements for Commodity-Backed Finance}

Commodity-backed finance usually needs the following:

1. Legal and regulatory framework. As seen above, warehouse receipt systems tend to require a relatively complex dedicated legal and regulatory framework. CMAs and SMAs are usually governed by the country's commercial contract laws, although some countries, like Côte d'Ivoire, do have specific laws for collateral management (tierce-détention).

2. Institutional support to an agency in charge of licensing and inspecting warehouses. Such support is needed to enable the operations of a formal warehouse receipt system. The licensing agency can be a public, private, or public-private institution, depending on the country, and more specifically on what configuration will inspire trust in the WRS from depositors, warehouse operators, and financial institutions. For CMA and SMA companies, there may be the need for licensing by a government authority based on minimum capital, demonstration of skills/professional competency, etc. (as in Mexico, for example).

3. Support to storage infrastructure and warehousing practices. An assessment of suitable warehouse facilities that could qualify for storage is often needed to identify gaps in the storage infrastructure's quantity and quality. Another key type of support consists in providing capacity building to warehouse or collateral managers to improve their technical skills, if and as needed. In some countries, governments provide financing through commercial banks for the upgrade, rehabilitation, or even construction of warehouses that cater to smallholder farmers (e.g., Mexico, Mozambique, and Sri Lanka).

4. Better awareness of and capacity in the use of commodities as collateral. Efforts to increase awareness and capacity should aim at various stakeholders, including producers, producer organizations, cooperatives, traders, and agricultural processors, as well as at the financial 
institutions that would be developing suitable lending products and procedures related to use of commodities as collateral.

\section{Recommendations for Developing Systems of Commodity-Backed Finance}

Several countries are getting interested in developing systems that would allow the use of commodities as collateral (as evidenced by current World Bank Group projects helping to introduce warehouse receipt systems in Côte d'Ivoire, Kenya, Malawi, and Senegal, and by pipeline projects for commoditybacked finance in Ethiopia, Ghana, and Niger). Recommendations on how to proceed depend heavily on each country's existing commodity markets and financial sector conditions, the status of the legal and regulatory environment, the organization of the storage industry, and the existence of professional collateral management companies, among many other variables. However, some general recommendations are likely to apply to many countries in early stages of developing systems to use commodities as a collateral. The list below highlights typical steps to support commodity-backed finance, while specifics on the exact content and implementation arrangements for such recommended actions would depend on the country and market context:

1. Scoping study to assess existing practices, the policy framework, and incentives for market participants to use inventories as collateral, as well as the appetite of stakeholders, notably financial institutions, to see commodity-backed finance expand

2. Assessment of the conditions, ownership, and management of storage facilities, particularly focusing on public third-party warehouses

3. Awareness raising, concept promotion, and advocacy among the various stakeholders (such as banks, the bank regulator, the government, producer organizations, and agribusinesses ${ }^{6}$ ) in favor of the use of commodity inventories as collateral for lending and the applicability of value chain finance for specific value chains

4. Development and dissemination of industry standards for warehouses, collateral management companies, stock monitoring companies, inspection and licensing procedures, etc.

5. Promotion of the use of professional collateral management services and stock monitoring services; strengthening of the industry association for collateral management and stock monitoring companies; and provision of dedicated training (e.g., through an academy) and licensing/certification for warehouse operators and stock monitoring staff to ensure high professional standards and procedures that would instill trust in the system

6. Provision of training to banks and bank regulators to explain the use of commodities as collateral for lending and design of appropriate financial products and procedures; identification of business development leads among value chains through commissioning of market studies to show opportunities for lending

7. Exploration of options for introducing electronic warehouse receipts, certificates of deposit, and receivables/invoices along with associated platforms

\footnotetext{
${ }^{6}$ In contexts where state-owned enterprises (SOEs) play a key role in agricultural financing, the International Finance Corporation has found that engaging with SOEs to show them the usefulness of commodity-backed financing can have a significant demonstration effect.
} 
8. Support to legal and regulatory reforms if and when needed

9. Support to the warehouse licensing and supervision body, if applicable

Lastly, note that two World Bank Group publications offer more details on the considerations for financial institutions in commodity-backed finance and the suggested approach for scoping, designing, and implementing warehouse receipt financing reforms: Warehouse Finance and Warehouse Receipt Systems: A Guide for Financial Institutions in Emerging Economies (IFC 2013) and Guide to Warehouse Receipt Financing Reform: Legislative Reform (World Bank 2016).

\section{References and Background Sources}

Coulter J. P., and G. E. Onumah. 2002. "The Role of Warehouse Receipt Systems in Enhanced Commodity Marketing and Rural Livelihoods in Africa." Food Policy 27: 319-37.

Hollinger F., L. Rutten, and K. Kiriakov. 2009. "The Use of Warehouse Receipt Finance in Agriculture in ECA Countries." Technical background paper for the World Grain Forum, St. Petersburg, June 6-7.

IFC (International Finance Corporation). 2013. Warehouse Finance and Warehouse Receipt Systems: $A$ Guide for Financial Institutions in Emerging Economies. Washington, DC: IFC.

Varangis, P., and D. Larson. 2002. "How Warehouse Receipts Help Commodity Trading and Financing." World Bank, Washington, DC.

World Bank. 2016. A Guide to Warehouse Receipt Financing Reform: Legislative Reform. Washington, DC: World Bank. 